\title{
KAJIAN KESEGARAN IKAN DI PASAR TRADISIONAL DAN MODERN KOTA MALANG
}

\author{
Eddy Suprayitno \\ Program Studi Teknologi Hasil Perikanan Fakultas Perikanan dan Ilmu Kelautan, \\ Universitas Brawijaya, Jl. Veteran, Malang, Indonesia \\ Koresponden penulis : eddysuprayitno@ub.ac.id
}

\begin{abstract}
Abstrak
Ikan mengandung protein dan juga memiliki kandungan gizi yang tinggi di antaranya mengandung mineral, vitamin, dan lemak tak jenuh. Produk perikanan tersebut merupakan produk yang memiliki sifat sangat mudah rusak/busuk. Hal ini terjadi karena adanya aktivitas enzim, mikroorganisme atau oksidasi oksigen. Penanganan bertujuan untuk menghambat proses penguraian jaringan tubuh (pembusukan) sehingga ikan dapat disimpan selama mungkin dalam keadaan baik. Oleh karena itu tujuan dari penelitian yaitu untuk mengetahui tingkat kesegaran ikan di pasar tradisional dan modern di Kota Malang secara kualittaif dan kuantitatif. Adapun sampel yang digunakan yaitu ikan selar, ikan kuniran, ikan bandeng, ikan mujair dan ikan kembung. Metode kualitatif digunakan untuk mengetahui tingkat kesegaran ikan berdasarkan penelitian organoleptik. Sedangkan metode kuantitatif digunakan untuk mengetahui nilai $\mathrm{pH}$ ikan, hasil uji formalin dan nilai TMA untuk mengetahui tingkat kesegaran ikan. Pengujian tingkat kesegaran ikan baik di pasar tradisional maupun modern secara organoleptik masih dalam keadaan yang segar dengan ciri-ciri daging bau khas ikan, insang merah, tidak banyak lendir, sisik menempel kuat, bola mata menonjol dan daging kenyal. Untuk nilai rata-rata $\mathrm{pH}$ ikan pada pasar tradisional dan modern yaitu sebesar 6,12. Untuk uji formalin terdapat 3 pasar dari 10 pasar yang ada di Kota Malang yang ikannya positif mengandung formalin yaitu pasar Blimbing, Mergan dan Giant Dinoyo. Pada uji TMA rerata nilai yang didapatkan yaitu 5,32 yang menunjukkan ikan dalam kondisi kurang segar.
\end{abstract}

Kata Kunci : Kesegaran, ikan, pasar, tradisional, modern

\begin{abstract}
Fish contains protein and also has a high nutrient content that contains minerals, vitamins, and unsaturated fats. Fishery product has very perishable properties. These are occurring because of the presence of enzymes, microorganisms or oxygen oxidation. The purpose of handling is inhibiting the decomposition process of the body tissue (decay) for saving fish in good condition. Therefore the purpose of the research was to find out the freshness of fish in traditional and modern markets in Malang City in a qualitative and quantitative manner. The samples used were selar fish, turmeric fish, milk fish, tilapia fish and mackerel. Qualitative method was applied to determine the freshness of fish based on organoleptic research. Moreover, the quantitative method used to determine the $\mathrm{pH}$ value of fish, the results of formalin test and the value of TMA to determine the freshness of the fish. The freshness test of fish both in traditional and modern markets through organoleptic-based still in a fresh condition with the characteristics of meat that smells typical of fish, red gills, not many fish slime, strong scales, prominent eyeballs and chewy meat. For the average value of $\mathrm{pH}$ of fish in traditional and modern markets were 6.12. For formaldehyde testing, there were 3 markets from 10 markets in Malang City which have positive formalin, namely Blimbing, Mergan and Giant Dinoyo Markets. The average value of TMA test was 5.32 which indicate that the fish was in a less fresh condition.
\end{abstract}

Keywords : Freshness, fish, market, traditional, modern

\section{PENDAHULUAN}

Kandungan protein ikan relatif tinggi yakni $15-25 \%$. Produk hasil perikanan juga mempunyai kelemahan yaitu cepat mengalami pembusukan dan penurunan mutu, proses penurunan mutu kesegaran ikan sangat dipengaruhi faktor internal maupun faktor eksternal. Faktor internal meliputi jenis dan ukuran ikan, bakteri dan enzim yang 
terkandung dalam tubuh ikan serta adanya oksidasi yang terjadi dalam tubuh ikan tersebut.

Banyak faktor yang menentukan kecepatan penurunan kesegaran ikan, diantaranya suhu penyimpanan. Penggunaan suhu rendah sekitar $0^{\circ} \mathrm{C}$ setelah ikan mati dapat memperpanjang masa kejang (rigor mortis), menurunkan kegiatan enzimatis, bakterial, kimiawi dan perubahan fisik sehingga dapat memperpanjang daya awet ikan. Cara kematian ikan pada saat penangkapan juga mempunyai pengaruh besar terhadap mutu dan daya awet ikan. Kematian ikan melalui perjuangan yang hebat pada setiap teknis penangkapan, cara penanganan yang kasar mengakibatkan ikan luka, memperpendek daya awet dan menurunkan mutu [1].

Perubahan yang dialami ikan berlangsung dalam tiga fase, yaitu fase prerigor mortis, rigor mortis, dan post-rigor mortis. Perubahan fase ini dapat digunakan sebagai indikator perubahan kualitas ikan. Sebelum fase post-rigor mortis, perubahan pada ikan disebabkan oleh aktivitas enzimatis. Perubahan yang disebabkan oleh oksidasi dan mikrobiologi berlangsung setelah memasuki fase post-rigor mortis

Banyak parameter yang dapat digunakan untuk menentukan tingkat kesegaran ikan, baik secara fisikawi, kimiawi, biologis dan organoleptik. Nilai $\mathrm{pH}$ merupakan parameter yang dapat digunakan untuk menentukan tingkat kesegaran hasil perikanan. Berdasarkan $\mathrm{pH}$, dapat ditentukan apakah daging ikan masih pada fase rigor mortis atau sudah memasuki fase post-rigor mortis. Pada fase pre-rigor kondisi otot ikan masih lunak, elastis dan lentur. Umumnya fase rigor mortis pada ikan terjadi satu hingga tujuh jam setelah ikan mati [2].

Ciri-ciri ikan segar antara lain mata jernih, kornea bening, pupil hitam, mata cembung dan insang merah segar. Jika kualitasnya menurun, insang berwarna keabuan, berlendir dan bau, sisik melekat kuat, mengkilap dan tertutup lendir jernih, aroma berbau khas ikan. Jika ikan tidak segar lagi, berbau busuk dan biasanya mengapung jika diletakkan di dalam air. Pada ikan yang masih segar, daging elastis dan bewarna cerah, dan jika ditekan tidak menimbulkan bekas permanen [3].
Tujuan dari penelitian ini adalah untuk mengetahui tingkat kesegaran ikan di pasar tradisional dan modern di Kota Malang secara kualitatif dan kuantitatif, sehingga akan terpetakan dan teridentifikasi sebaran kualitas ikan yang dipasarkan di Kota Malang.

\section{MATERI DAN METODE}

\section{Alat Penelitian}

Alat yang digunakan dalam penelitian ini antara lain, buku, nampan, alat tulis, kamera, plastik, pisau, talenan, mortal, alu, timbangan digital, pipet volume, bola hisap, $\mathrm{pH}$ meter, beaker glass, kertas saring, tabung reaksi, statif, buret, dan cawan conway.

\section{Bahan Penelitian}

Bahan yang digunakan dalam penelitian ini antara lain ikan selar, ikan kembung, ikan mujair, ikan kuniran, ikan bandeng, ikan sirip kuning, larutan buffer, aquadest, tissue, air, $\mathrm{KMnO} 4$, TCA 4\%, vaselin, Innering, Formaldehid, $\mathrm{K} 2 \mathrm{CO} 3$ jenuh, dan $\mathrm{HCl}$.

\section{Metode Penelitian}

Metode penelitian yang digunakan yaitu observasi dan wawancara untuk pengambilan data kesegaran ikan secara kualitatif serta ekperimental untuk uji $\mathrm{pH}$, formalin dan TMA. Adapun pasar tradisional yang digunakan sebagai tempat observasi adalah Pasar tradisional Gadang dengan sampel ikan selar, Pasar Blimbing dengan sampel ikan kembung, Pasar Mergan dengan sampel ikan bandeng, Pasar Besar dengan sampel ikan kuniran dan Pasar Bunulrejo dengan sampel ikan mujair. Sedangkan pasar modern yang digunakan sebagai tempat pengamatan adalah Pasar Modern Superindo dengan sampel ikan selar, Ranchmart dengan sampel ikan kembung, Giant Dinoyo dengan sampel ikan bandeng, Hypermart dengan sampel ikan kuniran dan pasar Hero dengan sampel ikan mujair.

Kemudian dilakukan wawancara kepada penjual ikan dipasar tradisional maupun modern dengan mengajukan beberapa pertanyaan seputar keadaan bahan baku ikan di pasar tersebut, metode pendinginan, jumlah perbandingan es dan ikan, waktu kedatangan 
ikan di pasar, jenis dan asal ikan yang dijual oleh pedagang tersebut, lama waktu pendistribusian, dan langkah apa yang dilakukan saat ikan tidak terjual.

\section{Pengujian Kesegaran Ikan}

Pengujian kesegaran ikan dengan uji organoleptik meliputi melihat dan mengamati penampilan ikan secara menyeluruh terutama penampilan fisik, mata, insang, dan ada tidaknya lendir. Kedua, yaitu dengan meraba ikan untuk mengamati kondisi ikan terutama adanya lendir, kelenturan ikan dan lainnya. Ketiga, dengan menekan daging ikan untuk menilai teksturnya. Keempat yaitu dengan mencium bau ikan tersebut.

Perubahan-perubahan yang terjadi setelah ikan mati menurut [4] secara garis besar adalah terjadinya rigormortis kemudian autolisis dan terakhir pembusukan yang meyebabkan selaput sel rusak. Rigor mortis berlangsung akibat tidak terjadinya aliran oksigen dalam jaringan peredaran darah oleh karena aktifitas jantung dan kontrol otaknya terhenti. Akibatnya didalam tubuh ikan tidak terjadi reaksi glikogenolisis yang dapat menghasilkan ATP sebagai sumber energi. Akibatnya reaksi berlangsung secara anaerobik yang memanfaatkan ATP dan glikogen dalam tubuh ikan sebagai sumber energi. Jumlah ATP akan terus berkurang dan $\mathrm{pH}$ tubuh menurun menyebabkan jaringan otot tidak mampu mernpertahankan fleksibilitasnya

\section{Uji pH}

Setiap sampel dihaluskan dengan mortal dan alu kemudian ditimbang menggunakan timbangan digital dengan ketelitian 10-2. Sampel diambil 1 gram untuk dilakukan uji $\mathrm{pH}$. Selanjutnya dimasukan dalam botol ipi, tambahkan $10 \mathrm{ml}$ aquades dan homogenkan Kemudian hitung nilai $\mathrm{pH}$ menggunakan $\mathrm{pH}$ meter.

Ikan yang menggelepar sebelum mati akan kehilangan banyak glikogen sehingga proses glikolisis berlangsung dalam waktu singkat dan fase rigor mortis lebih cepat terjadi. Ikan yang memiliki cadangan energi yang sedikit akan menyebabkan fase rigor mortis cepat berakhir. Fase rigor mortis akan berakhir ketika ATP telah habis terurai.
Kandungan asam laktat yang tinggi akibat kondisi stres sebelum mati akan menyebabkan nilai $\mathrm{pH}$ daging cepat menurun sehingga enzim katepsin aktif. Enzim katepsin ini akan menguraikan daging ikan menjadi senyawa yang lebih sederhana [5]

\section{Uji Formalin}

Setiap sampel dihaluskan menggunakan mortar dan alu. Lalu sampel ditimbang menggunakan timbangan digital seberat 10 gram. Kemudian sampel dimasukkan kedalam erlenmeyer dan ditambahkan aquades untuk melarutkan sampel. Lalu saring menggunakan kertas saring whatman. Selanjutnya masukkan pada tabung reaksi sebanyak $5 \mathrm{ml}$ dan tambahkan 5 tetes $\mathrm{KMnO} 40,1 \mathrm{~N}$ yang berfungsi untuk mengoksidasi aldehid dan homogenkan dengan spatula. Selanjutnya diamkan selama 30 menit dan amati perubahan warnanya. Jika larutan berubah menjadi bening dan ada endapan maka positif mengandung formalin.

\section{Uji TMA}

Sampel dihaluskan sampai lumat dengan mortal dan alu, kemudian ditimbang menggunakan timbangan digital sebanyak 5 gram. Selanjutnya sampel ikan dimasukkan ke dalam beaker glass dan dicampurkan dengan $10 \mathrm{~mL}$ TCA $4 \%$ yang berfungsi untuk mengikat senyawa amine dan turunannya kemudian tutup rapat dengan alumunium foil dan inkubasi pada suhu $18^{\circ} \mathrm{C}$ selama 30 menit. Kemudian saring menggunakan kertas Whatman nomor 1. Kemudian tambahkan sampel dengan TCA 4\% hingga volume akhir sampel $15 \mathrm{~mL}$.

Pengukuran TMA dilakukan menggunakan cawan conway yang telah dibersihkan dengan alkohol dan selanjutnya dioleskan vaselin pada pinggiran tutup dan ujung cawan. Pemberian vaseline bertujuan untuk menghindarkan penguapan larutan didalam conway. Unit cawan yang telah siap diletakkan pada alas mika putih dengan kemiringan $10^{\circ}$. Larutan sampel diteteskan sebanyak $1 \mathrm{~mL}$ dan ditambah formaldehid $10 \%$ sebanyak $1 \mathrm{ml}$ pada lingkaran terluar cawan conway sebelah kanan yang berfungsi 
untuk menguapkan senyawa amine dan turunannya kecuali TMA. Kemudian $1 \mathrm{~mL}$ larutan $\mathrm{K} 2 \mathrm{CO} 3$ jenuh diteteskan pada sebelah kiri untuk mengikat senyawa amine dan turunanya. Kedua larutan tidak boleh tercampur hingga lingkaran bagian dalam cawan conway terisi dengan $1 \mathrm{~mL}$ larutan innerring. Larutan inner ring ini berfungsi untuk menangkap senyawa amine dan turunannya. Setelah semua larutan dimasukkan pada tempatnya, cawan conway ditutup dan diletakkan secara mendatar sehingga larutan pada lingkaran terluar cawan tercampur dan homogenkan.

Selanjutnya cawan diinkubasi selama 2 jam pada suhu ruangan. Setelah masa inkubasi selesai, sisi lingkaran dalam dari cawan dititrasi dengan $0,02 \mathrm{~N} \mathrm{HCl}$. Titik akhir titrasi apabila warna dari larutan inner ring berubah seperti warna awal sebelum inkubasi (pink). Titik akhir titrasi blanko dan larutan sample dicatat kemudian dimasukkan kedalam rumus TMA untuk menentukan kadar TMA dari sampel ikan. Adapun rumus perhitungan TMA adalah sebagai berikut.

Total $\mathbf{N}=\mathrm{A} \times(\mathrm{B}-\mathrm{C}) \times 14$

Total TMA $=$ Total $\mathrm{N} \times 100$

Keterangan :

A : molaritas $\mathrm{HCl}$;

$\mathrm{B}$ : volume titrasi $\mathrm{HCl}(\mathrm{mL})$;

$\mathrm{C}$ : volume titrasi $\mathrm{HCl}$ blanko $(\mathrm{mL})$.

\section{HASIL DAN PEMBAHASAN}

\section{Karakteristik Ikan Segar}

Karakteristik ikan segar didapat sebagai berikut. Hasil pengamatan sampel ikan selar dari pasar tradisional Gadang Malang, diperoleh nilai organoleptik yang baik, penampilan fisik mengkilat, berbau amis spesifik ikan segar, matanya jernih dan cembung, dagingnya masih kenyal, sisik masih menempel erat pada kulit, insangnya berwarna merah cerah. Hal ini sama dengan karakteristik kesegaran ikan di Pasar tradisional Blimbing Malang. Adapun ikan mujair yang berasal dari pasar tradisional Bunulrejo terlihat segar dan mengkilat, dagingnya kenyal padat, matanya bening pupil hitam, sisik merah segar, insang merah kecoklatan, dan berlendir. Sedangkan untuk ikan ikan kuniran yang berasal dari Pasar Tradisional Besar Malang terlihat mengkilat, daging kenyal, mata jernih cembung, sisik menempel erat, dan insang merah kecoklatan. Serta untuk ikan bandeng yang berasal dari Pasar Tradisional Mergan terlihat seperti ikan segar, kenyal, mata bening dan insangnya merah pudar.

Sedangkan analisa organoleptik dari Pasar Modern Superindo dengan sampel ikan selar terlihat mengkilat dan berbau segar, daging kenyal padat, kornea jernih, pupil menghitam, sisik menempel erat, dan insang berwarna merah. Pasar Modern Hypermart dengan sampel ikan kuniran terlihat warna mengkilat, segar, daging kenyal, mata sedikit cekung dan buram, insang, serta sisik menempel kuat. Selanjutnya Pasar Modern Giant Dinoyo dengan sampel ikan bandeng, sisik mulai lepas dan bau mulai busuk, lembek jika ditekan, mata buram ada darah dan insang berwarna coklat. Untuk Pasar Modern Hero dengan sampel ikan mujair terlihat warna mengkilat segar, bau amis segar, daging kenyal lunak, mata cembung jernih, sisik menempel kuat dan insang berwarna merah. Serta Pasar Modern Ranchmart dengan sampel ikan ekor kuniran terlihat bagian luarnya bagus, dagingnya kenyal, mata cembung, pupil hitam, sisik menempel erat, dan tidak berlendir.

Ciri-ciri dari ikan segar itu sendiri yakni bola mata menonjol, warna bola mata merah cerah, kenampakan cemerlang mengkilat, daging masih utuh, dan bagian perut masih utuh, matanya bening, korneanya jernih, pupil hitam dan menonjol, insang berwarna kemerahan dan tidak berlendir, baunya spesifik ikan segar, dan tekstur dagingnya pejal dimana jika ditekan tidak meninggalkan bekas jari [6].

Adapun faktor yang mempengaruhi kesegaran ikan ialah daerah penangkapan, pencemaran daerah, penggunaan es sebagai pendingin, cara penyimpanan, suhu, cuaca, dan penanganan pasca panen.

\section{Analisa pH}

Uji pH dapat dijadikan sebagai indikator tingkat kesegaran ikan. Hasil 
pengujian $\mathrm{pH}$ pada beberapa pasar tradisional dan modern di Kota Malang sebagai berikut.

Tabel 1. Nilai pH

\begin{tabular}{lcc}
\hline \multicolumn{1}{c}{ Jenis Ikan } & Nama Pasar & $\begin{array}{c}\text { Nilai } \\
\text { pH }\end{array}$ \\
\hline \multirow{3}{*}{ Ikan selar } & Pasar Tradisional Gadang & 6,46 \\
& Pasar Modern Superindo & 5,7 \\
Ikan mujair & Pasar Tradisional & 5,72 \\
& Bunulrejo & \\
& Pasar Modern Hero & 6,14 \\
Ikan bandeng & Pasar Tradisional Mergan & 5,96 \\
& Pasar Modern Giant & 6,79 \\
Ikan kembung & Dinoyo & \\
& Pasar Tradisional & 5,43 \\
& $\quad$ Blimbing & \\
Ikan kuniran & Pasar Modern Ranchmart & 6,37 \\
& Pasar Tradisional Besar & 6,26 \\
& $\quad$ Malang & \\
& Pasar Modern Hypermart & 6,40 \\
\hline
\end{tabular}

Berdasarkan hasil uji $\mathrm{pH}$ untuk $\mathrm{pH}$ tertinggi dari pasar tradisional yaitu Pasar Gadang sebesar 6,46 dan terendah 5,43 dari Pasar Blimbing. Sedangkan $\mathrm{pH}$ tertinggi pasar modern yaitu Pasar Giant Dinoyo 6,79 dan terendah 5,70 dari swalayan Superindo. Nilai $\mathrm{pH}$ untuk ikan pre rigor yaitu 6,9-7,2, ikan rigor mortis 6,2-6,6 dan ikan post rigor yaitu 7,5-8,0. Dari hasil uji $\mathrm{Ph}$ maka ikan masih dalam katergori ikan segar yaitu ikan pre rigor dan rigor mortis.

Nilai $\mathrm{pH}$ merupakan salah satu indikator yang digunakan untuk menentukan tingkat kesegaran ikan. Pada proses pembusukan ikan, perubahan $\mathrm{pH}$ daging ikan sangat besar peranannya karena berpengaruh terhadap proses autolisis dan penyerangan bakteri. Semakin rendah suhu yang digunakan maka aktivitas enzim semakin terhambat. Pada proses glikolisis, enzim sangat berperan sampai terbentuknya asam laktat. Hal ini menyebabkan akumulasi asam laktat berjalan lebih lambat sehingga penurunan $\mathrm{pH}$ ikan juga berlangsung lebih lambat. Selain itu, proses penguraian protein menjadi senyawa-senyawa yang bersifat basa oleh bakteri juga terhambat sehingga peningkatan $\mathrm{pH}$ ikan berlangsung lebih lambat [7].

\section{Analisa Hasil Uji Formalin}

Formalin dapat menimbulkan efek kenyal, dan awet. Sehingga formalin banyak disalahgunkan untuk mengawetkan ikan. Hasil uji formalin dari pasar tradisional dan modern sebagai berikut.

Tabel 2. Hasil Uji Formalin

\begin{tabular}{lcc}
\hline Nama Ikan & Pasar & $\begin{array}{c}\text { Hasil } \\
\text { Analisa }\end{array}$ \\
\hline Ikan Selar & Pasar Tradisional & - \\
& Gadang & \\
& Pasar Modern & - \\
Superindo & \\
Ikan & Pasar Tradisional & \\
Kembung & Blimbing & + \\
& Pasar Modern & - \\
& Ranchart & \\
Ikan Mujair & Pasar Tradisional & - \\
& Bunulrejo & \\
& Pasar Modern Hero & - \\
Ikan Kuniran & Pasar Tradisional & - \\
& Besar Malang & \\
& Pasar Modern & - \\
& Hypermart & \\
Ikan Bandeng & Pasar Tradisional & + \\
& Mergan & + \\
& Pasar Modern \\
& Giant Dinoyo & + \\
\hline
\end{tabular}

Tabel 2 menunjukkan bahwa sampel ikan dari pasar yang berbeda, positif mengandung formalin yaitu berasal dari Pasar Tradisional Belimbing, Pasar Tradisional Mergan dan Pasar Modern Giant Dinoyo. Formalin dimanfaatkan untuk menjaga tingkat kesegaran ikan supaya memiliki daya simpan yang lebih lama. Formalin merupakan bahan kimia yang tidak berwarna dan berbau sangat menusuk Gugus aldehid yang dimiliki oleh formalin yang mampu bereaksi dengan protein ikan sehingga ikan menjadi kenyal dan awet [8]

\section{Analisa Uji TMA}

TMA (trimethylamine) merupakan indikator tingkat kesegaran ikan. Hasil pengujian TMA pada sampel ikan yang diambil dari pasar Tradisional maupun Pasar Modern Kota Malang sebagai berikut. 
Tabel 3. Hasil Uji TMA

\begin{tabular}{lcc}
\hline Nama Ikan & Pasar & TMA \\
\hline & Pasar & \\
Ikan Selar & Tradisional & 5,6 \\
& Gadang & \\
& Pasar & \\
& Modern & 1,4 \\
& Superindo & \\
& Pasar & \\
& Tradisional & 5,6 \\
Ikan Kembung & Blimbing & \\
& Pasar & \\
& Modern & 2,8 \\
& Ranchmart & \\
& Pasar & \\
Ikan Mujair & Tradisional & 15,4 \\
& Bunulrejo & \\
& Pasar & \\
& Modern & 4,2 \\
& Hero & \\
& Pasar & \\
Ikan & Tradisional & 4,2 \\
Kuniran & Besar & \\
& Malang & \\
& Pasar & \\
& Modern & 2,8 \\
& Hypermart & \\
Ikan & Pasar & \\
Bandeng & Tradisional \\
& Mergan & 8,4 \\
& Pasar & \\
& Modern & 2,8 \\
& Giant & \\
& Dinoyo & \\
& & \\
& &
\end{tabular}

Berdasarkan tabel 3 didapat nilai tertinggi TMA yaitu sebesar 15,4 pada pasar Tradisional Bunulrejo dan terendah diperoleh pasar Modern Hypermart, Giant Dinoyo, Ranchmart dengan nilai TMA sebesar 2,8. Batas nilai maksimum pada pengujian TMA yaitu sebesar 2-3 mg/100 g sampel. Semakin tinggi nilai TMA semakin banyak TMAO yang telah dipecah menjadi TMA oleh bakteri. Sehingga tingkat kesegaran ikan sudah mulai menurun.

TMA ini merupakan hasil dari reduksi TMAO oleh enzim. Pada kasus pembusukan ikan, mikroorganisme memanfaatkan atom oksigen yang disumbangkan oleh TMAO dalam kondisi anaerob dan mengakibatkan peningkatan pembentukan TMA. Jenis mikroba yang berperan pada proses pembusukan ikan sebagian besar terdiri dari bakteri gram-negatif dari jenis Pseudomonas,
Alteromonas, Shewanella, Moraxella, Acinetobacter, Vibrio, Flavobacterium dan CytopHaga. Jenis mikroba pembusuk aerob dari ikan yang disimpan di es terdiri terutama dari jenis Pseudomonas spp. dan Shewanella putrefaciens [9]

\section{KESIMPULAN}

Pengujian tingkat kesegaran ikan baik di pasar tradisional maupun modern secara organoleptik masih dalam keadaan yang segar dengan ciri-ciri daging bau khas ikan, insang merah, tidak banyak lendir, sisik menempel kuat, bola mata menonjol dan daging kenyal. Untuk nilai rata-rata $\mathrm{pH}$ ikan pada pasar tradisional dan modern yaitu sebesar 6,12. Untuk uji formalin terdapat 3 pasar dari 10 pasar yang ada di Kota Malang yang ikannya positif mengandung formalin yaitu pasar Blimbing, Mergan dan Giant Dinoyo. Serta untuk uji TMA rerata nilai yang didapatkan yaitu 5,32 yang menunjukkan ikan dalam kondisi kurang segar karena melebihi batas maksimal TMA yaitu 2-3 mg/100 gram sampel.

\section{UCAPAN TERIMA KASIH}

Penulis berterimakasih kepada berbagai pihak yang telah membantu penelitian ini.

\section{DAFTAR PUSTAKA}

[1] Reo, Albert R. 2010. Pengaruh Beberapa Cara Kematian Ikan Terhadap Mutu Ikan Kakap (Lutjanus Sp.). Jurnal Perikanan dan Kelautan Tropis .6(3) : 145-148.

[2] Liviawaty, E. dan E. Afrianto. 2014. Penentuan Waktu Rigor Mortis Ikan Nila Merah (Oreochromis Niloticus) Berdasarkan Pola Perubahan Derajat Keasaman. Jurnal Akuatika.5(1): 40-44

[3] Siburian, E. T. P., P. Dewi dan N. Kariada. 2012. Pengaruh Suhu dan Waktu Penyimpanan Terhadap Pertumbuhan Bakteri dan Fungi Ikan Bandeng. Unnes Journal of Life Science. 1 (2) : 101-105. 
[4] Sanger,G. 2010. Mutu Kesegaran Ikan Tongkol (Auxis tozard) Selama Penyimpanan Dingin. Warta WIPTEK. $35: 39-43$.

[5] Nurilmala, M., Nurjanah dan R.H. Utama. 2009. Kemunduran Mutu Ikan Lele Dumbo (Clarias gariepinus) Pada Penyimpanan Suhu Chilling dengan Perlakuan Cara Mati..Jurnal Pengolahan Hasil Perikanan. 12(1) : 1-16.

[6] Riyanto, I., W.Abida dan A. Fuad. 2009. Tingkat Ketahanan Kesegaran Ikan Mas (Ciprynus carpia) Menggunakan Asap Cair. Jurnal Kelautan .2(1) : 66-72.

[7] Munandar, A., Nurjanah dan $M$. Nurilmala. 2009. Kemunduran Mutu Ikan Nila (Oreochromis niloticus) Pada
Penyimpanan Suhu Rendah Dengan

Perlakuan Cara Kematian dan

Penyiangan. Jurnal Teknologi Pengolahan Hasil Perikanan Indonesia.11(2) : 88-101.

[8] Syamsul Bihar. 2013. Ancaman Bahaya Formalin terhadap Kesehatan Kita. www.analisadaily.com (Akses 18 november 2018).

[9] Muritini, J.T, R. Riyanto, N. Priyanto dan I. Hermana. 2014. Pembentukan Formaldehid Alami Pada Beberapa Jenis Ikan Laut Selama Penyimpanan Dalam Es Curia. JPB Perikanan. 9(2): 143-151. 